\title{
WISATA OUTBOUND DI KOTA SINGKAWANG
}

\author{
Dini Asih Setiarini' ${ }^{1}$, Syaiful Muazir², Hamdil Khaliesh ${ }^{3}$ \\ ${ }^{1}$ Mahasiswa, Program Studi Arsitektur, Fakultas Teknik, Universitas Tanjungpura \\ diniasihsetiarini1998@gmail.com \\ ${ }^{2}$ Program Studi Arsitektur, Fakultas Teknik, Universitas Tanjungpura \\ ${ }^{3}$ Program Studi Arsitektur, Fakultas Teknik, Universitas Tanjungpura
}

Naskah diajukan pada: 30 Januari 2021

Naskah revisi akhir diterima pada: 3 Februari 2021

\begin{abstract}
Abstrak
Penurunan kinerja pada karyawan baik swasta maupun negeri semakin hari semakin memburuk. Memburuknya kinerja karyawan tersebut memberi pengaruh yang besar terhadap instansinya. Terdapat beberapa cara yang dilakukan untuk meningkatkan kinerja tersebut, salah satu cara yang efektif yang dilakukan yaitu melakukan pelatihan sekaligus perjalanan wisata. Pelatihan dan perjalanan wisata ini biasanya dikenal dengan istilah outbound. Selain dapat dilakukan oleh pegawai atau karyawan outbound biasanya juga dilakukan dari berbagai kalangan dari anak sekolah dan kuliah serta dari kalangan umum. Outbound adalah suatu bentuk dari pembelajaran segala ilmu terapan yang disimulasikan dan dilakukan di alam terbuka atau tertutup dengan bentuk permainan yang efektif, yang menggabungkan antara intelegensia, fisik, dan mental. Outbound merupakan salah satu management training yang merupakan perpeduan dari olahraga alam terbuka, permainan ketangkasan dan petualangan dengan konsep alam yang bertujuan untuk membentuk, mengarahkan, menyampaikan visi, sekaligus berekreasi bagi para pesertanya. Kota Singkawang merupakan kota yang terkenal dengan destinasi wisata yang beragam. Selain itu, di Kota Singkawang juga terdapat area-area yang berpotensi untuk dibangun Wisata Outbound. Wisata Outbound di Kota Singkawang ini tidak hanya memfasilitasi permainan saja, namun terdapat fasilitas perkemahan dan penunjang lainnya.
\end{abstract}

Kata-kata kunci: Wisata, Outbound, Kota Singkawang

\begin{abstract}
The decline in performance of both private and public employees is getting worse day by day. The worsening of the employee's performance had a big impact on the agency. There are various ways that can be done to improve the performance, one of the effective ways to do is to conduct training as well as travel tours. This training and tour is usually known as outbound. Apart from being able to be done by employees or outbound employees, it is usually also carried out from various circles, from school and college children as well as from the general public. Outbound is a form of learning all applied sciences that is simulated and carried out in an open or closed environment with an effective form of play, which combines intelligence, physical and mental. Outbound is a management training which is a combination of outdoor sports, dexterity and adventure games with the concept of nature which aims to shape, direct, convey a vision, as well as have recreation for the participants. Singkawang City is a city famous for its various tourist destinations. In addition, in Singkawang City, there are areas that have the potential to be built for Outbound Tourism. Outbound tourism in Singkawang City not only facilitates games, but there are camping and other supporting facilities.
\end{abstract}

Keywords: Tourism, Outbound, Singkawang City

\section{Pendahuluan}

Menurut Kementerian Pendayagunaan Aparatur Negara dan Reformasi Birokrasi (KemenpanRB) mengungkapkan, ada 30\% atau sekitar 1,35 juta pegawai negeri sipil (PNS) yang kinerjanya tergolong buruk (Antoni, Angga, \& Akmal, 2018). Ketika melaksanakan tugas, masih banyak pegawai yang belum mampu memaksimalkan diri sehingga kinerja yang diberikan terhadap instansi dan perusahaan dibawah standar. Jumlah yang belum maksimal ini tergolong besar serta 
mempengaruhi kontribusi terhada perusahaan. Hal ini sebenarnya dapat diatasi dan diperbaiki dengan melakukan pendekatan yang serius seperti "Human Capital Management" (Hartono \& Dwi, 2019). Salah satu upaya untuk mencapai hal tersebut, beberapa perusahaan melakukan perjalanan wisata ataupun pelatihan untuk meningkatkan kualitas kinerja mereka.

Wisata yang sedang trend saat ini yaitu Outbound. Outbound merupakan salah satu jenis management training yang merupakan wisata di alam terbuka dengan permainan ketangkasan. Wisata ini dilakukan oleh berbagai pihak. Pada tahun 2018 di Kalimantan Barat, sebagian besar sekolah dari jenjang TK hingga SMA melakukan kegiatan outbound sebagai salah satu pilihan wisata. Selain sekolah, wisata outbound menjadi pilhan wisata bagi beberapa organisasi. (Yanuarius, 2018)

Outbound adalah suatu bentuk dari pembelajaran segala ilmu terapan yang disimulasikan dan dilakukan di alam terbuka atau tertutup dengan bentuk permainan yang efektif, yang menggabungkan antara intelegensia, fisik, dan mental (Nanda, 2018). Outbound merupakan salah satu management training yang merupakan perpeduan dari olahraga alam terbuka, permainan ketangkasan dan petualangan dengan konsep alam yang bertujuan untuk membentuk, mengarahkan, menyampaikan visi, sekaligus berekreasi bagi para pesertanya. Dari program outbound tersebut akan diperoleh pembelajaran yang meningkatkan skill. Outbound Management Training memberikan pengaruh terhadap potensi organisasi secara keseluruhan yang terdiri dari lima variable yaitu komitmen kepada tugas, keterbukaan dalam bersikap, kecakapan dalam bekerja, kebersamaan dalam hubungan sosial dan integritas pribadi yang tinggi. Kegiatan outbound tidak hanya menjadi program training management semata, akan tetapi menjadi salah satu wisata yang dapat dilakukan oleh semua usia, karena metode yang digunakan dalam outbound penuh dengan kegembiraan sebab diselaraskan dengan permainan yang menarik. Kegiatan outbound sebuah permainan yang merupakan simulator tentang masalah-masalah sesungguhnya yang ditemukan dalam kehidupan dan biasanya dilakukan diruang terbuka.

Salah satu capaian misi Kota Singkawang yang dipersiapkan menjelang tahun 2020 dalam rancangan prioritas pembangunan di Singkawang, adalah mengembangkan kawasan dan peningkatan pertumbuhan ekonomi meliputi kegiatan fasilitasi destinasi wisata. Salah satu kecamatan di Kota Singkawang yang memiliki potensi wisata dan akan dikembangkan adalah Kecamatan Singkawang Timur (Rendra, 2019). Dengan potensi tersebut, Kota Singkawang berpeluang untuk pertumbuhan area wisata. Dari penjabaran di atas disimpulkan bahwa dibutuhkannya tempat untuk mewadahi aktifitas outbound dengan konsep alami.

\section{Kajian Pustaka}

Menurut Undang-Undang Nomor 10 tahun 2009 tentang Kepariwisataan Bab I Pasal 1 berbunyi bahwa wisata adalah kegiatan perjalanan yang dilakukan oleh seorang atau sekelompok orang dengan mengunjungi tempat tertentu untuk tujuan rekreasi, pengembangan pribadi, atau mempelajari keunikan daya Tarik wisata yang dikunjungi dalam rangka waktu yang sementara. Outbound berasal dari kata out of boundaries, artinya keluar dari batas. Hal ini merupakan istilah dibidang kelautan yang menandakan saat - saat sebuah kapal keluar dari dermaga dan melewati batas perairan. Metode Training Outbound di alam terbuka yang dikembangkan berfungsi sebagai katalis, sebagai medium perubahan dan membantu setiap peserta untuk lebih dapat mengenal kelemahan dan kelebihan masing - masing individu (Alikhshan, 2016). Secara teoritis, dapat dikatakan bahwa outbound adalah suatu bentuk dari pembelajaran segala ilmu terapan yang disulasikan dan dilakukan di alam terbuka atau tertutup dengan bentuk permainan yang efektif, yang menggabungkan antara intelegensia, fisik dan mental. Berdasarkan definisi tersebut Wisata Outbound merupakan tempat yang direncanakan untuk seorang atau kelompok yang bertujuan melakukan kegiatan pelatihan di alam terbuka. 
Tabel 1. Kriteria dan standar minimal sarana prasarana daerah wisata

\begin{tabular}{|c|c|c|c|}
\hline No. & Kriteria & Standar Minimal & Fasilitas \\
\hline & Obyek & $\begin{array}{l}\text { Terdapat salah satu dari unsur alam, sosial, atau } \\
\text { budaya }\end{array}$ & Objek wisata \\
\hline 2. & Akses & $\begin{array}{l}\text { Adanya jalan, adanya kemudahan rute, tempat } \\
\text { parkir, dan harga parkir yang terjangkau }\end{array}$ & $\begin{array}{l}\text { Jalan dan Parkir } \\
\text { kendaraan }\end{array}$ \\
\hline 3. & Akomodasi & $\begin{array}{l}\text { Adanya pelayanan penginapan (hotel, wisma, } \\
\text { losmen, dan lain-lain) }\end{array}$ & Penginapan \\
\hline & fasilitas & $\begin{array}{l}\text { Agen perjalanan, pusat informasi, fasilitas } \\
\text { kesehatan, pemadam kebakaran, hydrant, , plang } \\
\text { informasi, petugas entry dan exit }\end{array}$ & Area informasi \\
\hline & Transportasi & $\begin{array}{l}\text { Adanya moda transportasi yang nyaman sebagai } \\
\text { akses masuk }\end{array}$ & - \\
\hline & Catering Service & $\begin{array}{l}\text { Adanya pelayanan makanan dan minuman } \\
\text { (restoran dan rumah makan, warung nasi dan } \\
\text { lain-lain). }\end{array}$ & $\begin{array}{l}\text { Restoran } \\
\text { kafe }\end{array}$ \\
\hline & Aktifitas rekreasi & $\begin{array}{l}\text { Aktifitas di lokasi wisata seperti berenang, jalan- } \\
\text { jalan, dan lain-lain }\end{array}$ & Objek rekreasi \\
\hline & Pembelanjaan & Tempat pembelian barang-barang umum & minimarket \\
\hline & Komunikasi & $\begin{array}{l}\text { Adanya TV, sinyal telepon, akses internet, } \\
\text { penjual voucher pulsa. }\end{array}$ & - \\
\hline & Sistem Perbankan & Adanya bank dan ATM & ATM \\
\hline & Kesehatan & Pelayanan kesehatan & Pos Kesehatan \\
\hline & Keamanan & $\begin{array}{l}\text { Adanya jaminan keamanan (petugas } \\
\text { keamanan, polisi wisata, pengawas } \\
\text { rambu-rambu perhatian, pengarah } \\
\text { wisatawan) }\end{array}$ & Pos Keamanan \\
\hline 13. & Kebersihan & $\begin{array}{l}\text { Adanya tempat sampah dan rambu-rambu } \\
\text { peringatan tentang kebersihan }\end{array}$ & $\begin{array}{l}\text { Fasilitas } \\
\text { kebersihan }\end{array}$ \\
\hline & Sarana Ibadah & Terdapat salah satu sarana ibadah bagi wisatawan & Mushola \\
\hline & Sarana Olahraga & $\begin{array}{l}\text { Terdapat alat dan perlengkapan untuk } \\
\text { berolahraga }\end{array}$ & - \\
\hline
\end{tabular}

Sumber: Yoeti, 1996 \& PERMENPAR RI NO. 3 Tahun 2018

Adapun jenis-jenis outbound, yaitu outbound yang lebih menekankan terhadap kemampuan fisik (real outbound) dan outbound yang lebih ringan dan lebih mudah dilakukan (fun outbound). Pada Fun Outbound kegiatan di dalamnya tidak begitu menekankan pada kekuatan fisik pesertanya, sehingga banyak pendapat yang mengatakan bahwa fun outbound bukanlah outbound yang sesungguhnya, yang termasuk dalam fun outbound antara lain, group invinite dan low ropes cours. Real Outbound, kegiatan outbound ini memerlukan suatu ketahanan dan fisik yang cukup besar. pada outbound ini, peserta akan melakukan suatu petualangan (adventure), yang penuh tantangan. Adapun kegiatan-kegiatannya seperti; high rope cours, wall climbing, paintball, ATV ride.

\section{Metode}

Metode perancangan Wisata Outbound di Kota Singkawang mengacu kepada metode perancangan menurut J. C. Jones yang terdiri dari 6 tahap yaitu gagasan, informasi, analisisi, sintesis, evaluasi, dan optimalilasi (Nuraini, 2010). Pada tahapan gagasan, dimulai dengan penentuan judul yaitu "Wisata Outbound di Kota Singkawang", pencarian ide dan gagasan yang melatarbelakangi perancangan, kemudian merumuskan masalah, tujuan sasaran, manfaat, dan lingkup tugas. Pada tahap informasi, mencari dan memaparkan data. Data terdiri dari 2 jenis, yaitu primer dan sekunder. Data 
primer yaitu data tapak perancangan Wisata Outbound di Kota Singkawang, sedangkan data sekunder yaitu teori-teori yang diperoleh dari literatur - literatur tentang Wisata Outbound. Tahap analisis, berupa analisis internal, eksternal, bentuk, struktur, utilitas, dan fisika bangunan pada perancangan Wisata Outbound di Kota Singkawang. Tahap Sintesis berupa perumusan konsep perancangan Wisata Outbound dari hasil pada tahapan analisis sebelumnya. Tahap evaluasi berupa rancangan skematik pada perancangan Wisata Outbound. Tahap optimalisasi berupa pengaplikasian dan pengoptimalisasikan konsep Wisata Outbound terhadap gambar denah, tampak, potongan dan lainlain.

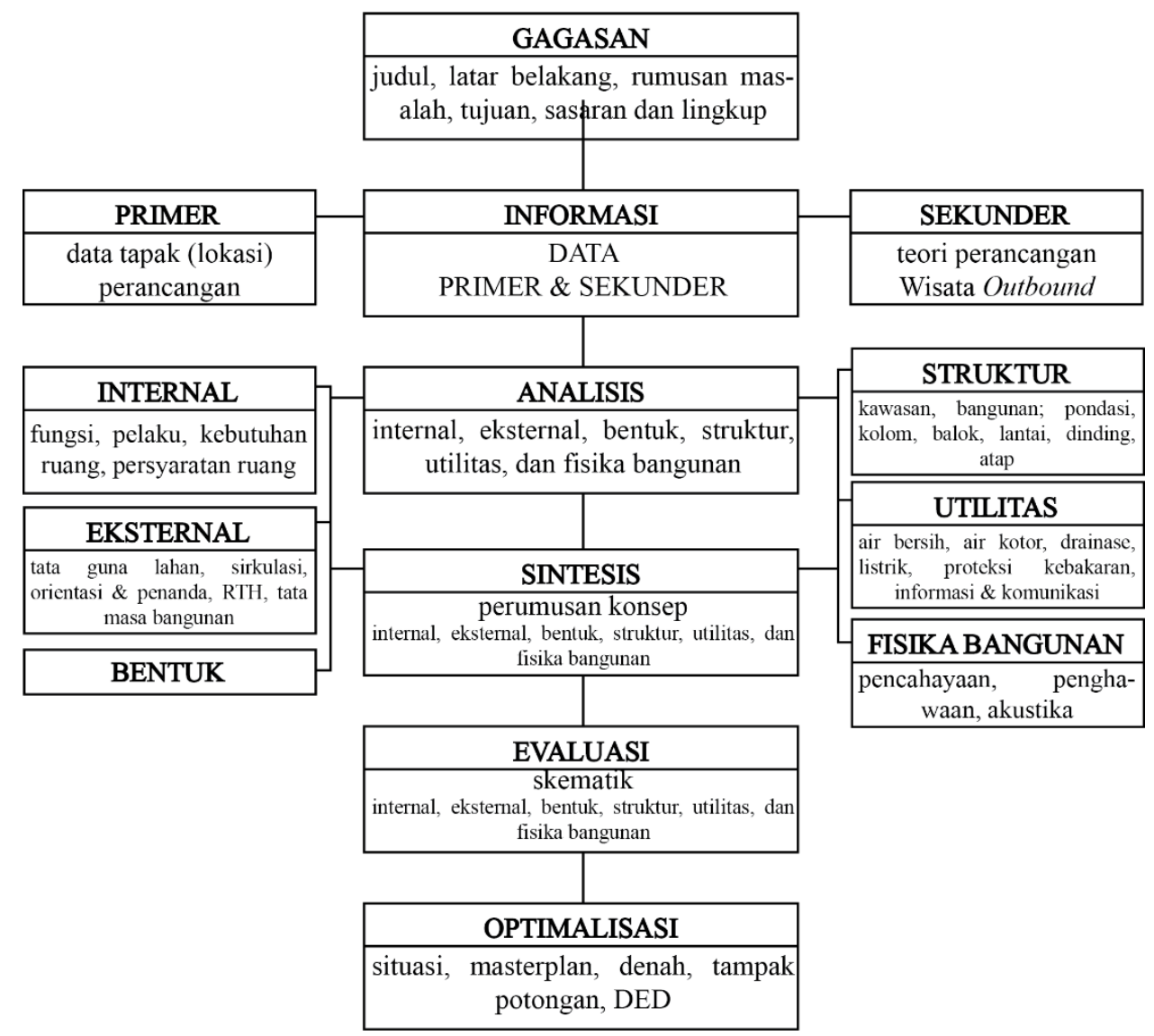

Gambar 1. Proses perancangan Wisata Outbound di Kota Singkawang

Sumber: Penulis, 2020

\section{Hasil dan Pembahasan}

Hasil dan pembahasan merupakan penjelasan terkait konsep yang diterapkan pada perancangan kawasan Wisata Outbound di Kota Singkawang yang diperoleh dari analisis yang telah dilakukan sebelumnya. Analisis terdiri dari analisis internal, analisis eksternal, konsep bentuk, konsep stuktur, konsep utilitas, konsep fisika bangunan dan hasil perancangan berupa masterplan, denah, tampak, potongan, dan perspektif luar dan dalam bangunan.

\section{Internal}

Wisata Outbound di Kota Singkawang memiliki fungsi utama rekreasi serta fungsi pendukung komersil dan pengelola. Pelaku pada Wisata Outbound di Kota Singkawang pelaku pada Wisata Outbound di Kota Singkawang terbagi menjadi dua kelompok, kelompok pengunjung dan kelompok pengelola. Pada kelompok pengunjung, dibedakan berdasarkan umur, yaitu kelompok pengunjung anak dan kelompok pengunjung dewasa. Dari identifikasi pelaku dan kegiatannya didapat ruangruang yang harus disediakan, seperti pada tabel 2. 
Tabel 2. Kebutuhan ruang pada Wisata Outbound di Kota Singkawang

\begin{tabular}{lcc}
\hline \multicolumn{1}{c}{ Ruang } & Zoining & Luas $\left.\mathbf{( m}^{\mathbf{2}}\right)$ \\
\hline AREA PENERIMAAN & Public & 60,2 \\
\hline $\begin{array}{l}\text { KANTOR PENGELOLA } \\
\text { \& INFORMASI }\end{array}$ & Public & 645,55 \\
\hline MUSHOLLA & Service & 77,924 \\
\hline POS KESEHATAN & Service & 46,55 \\
\hline $\begin{array}{l}\text { OUTBOUND TRAINING } \\
\text { AREA }\end{array}$ & Semi Private & 850 \\
\hline KAFE & Semi Public & 604,8 \\
\hline PENGINAPAN & Private & 726,18 \\
\hline TAMAN & Semi Public & 884,8 \\
\hline PAINTBALL & Semi Private & 976,65 \\
\hline ARENA ATV & Semi Private & 1095,65 \\
\hline CLIMBING WALL & Semi Private & 891,65 \\
\hline LOW ROPE COURS & Semi Private & 650 \\
\hline HIGH ROPE COURS & Semi Private & 650 \\
\hline AREA PERKEMAHAN & Semi Private & 700,7 \\
\hline PARKIR PENGUNJUNG & Service & 675 \\
\hline PARKIR PENGELOLA & Service & 66,15 \\
\hline SIRKULASI 70\% & & 7916,13 \\
\hline TOTAL LUAS & & 19164,70 \\
\hline
\end{tabular}

Sumber: Penulis, 2020

Dari kebutuhan ruang dan persyaratan ruang yang telah di analisis, kemudian di rumuskan kedalam konsep hubungan ruang. Konsep hubungan ruang yang diperoleh terdiri dari area penerima, pengelola, dan area bermain. Area bermain dibagi berdasarkan tingkatan keamanan saat bermain. Area bermain yang memiliki tingkat keamanan yang tinggi hanya bisa di akses oleh pengunjung dengan tingkatan usia tertentu.

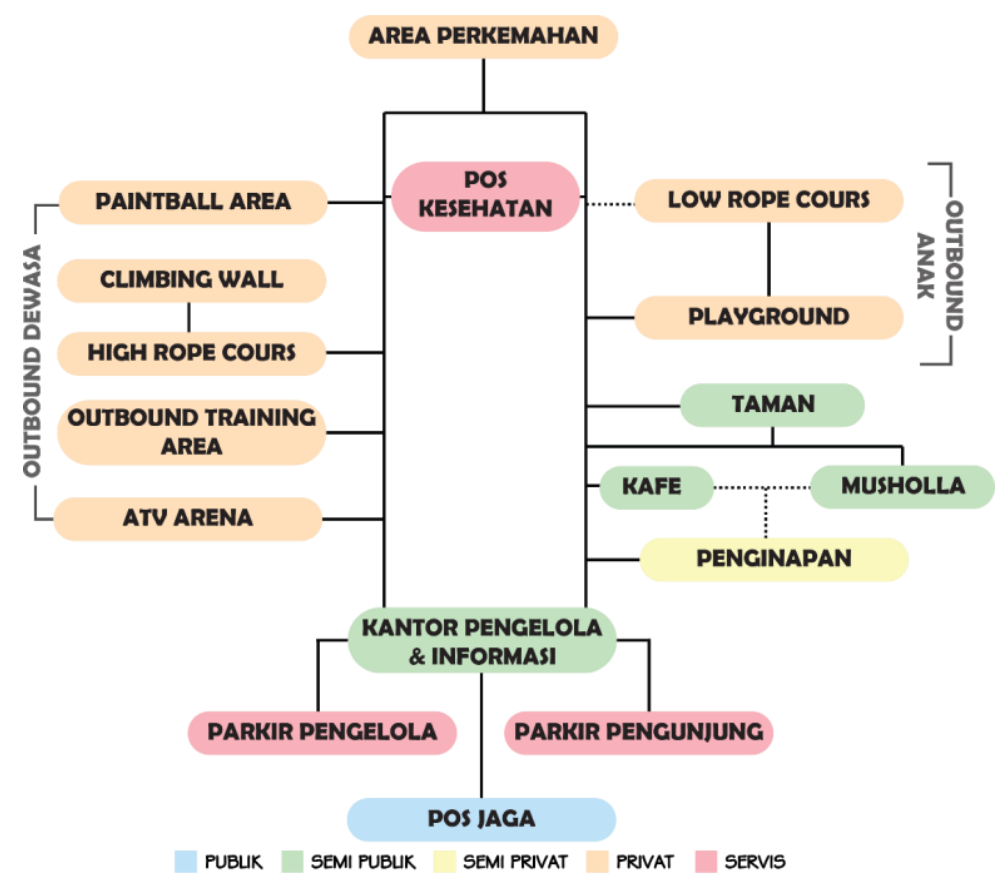

Gambar 2. Organisasi ruang makro kawasan Wisata Outbound di Kota Singkawang Sumber: Penulis, 2020 


\section{Eksternal}

Lokasi perancangan Wisata Outbound di Kota Singkawang berada di Jl. Raya SingkawangBengkayang, Kelurahan Bagak Sahwa, Kecamatan Singkawang Timur, Kota Singkawang. Kalimantan Barat. Luas tapak sekitar 7,5 Hektar atau 75.000 m2. Garis Sempadan Bangunan (GSB) sebesar 25 meter, Koefisien Dasar Bangunan (KDB) maksimal 40\%, Koefisien Lantai Bangunan (KLB) 1,0, Koefisien Dasar Hijau (KDH) minimal 30\%, serta lebar jalan 4,8 m.

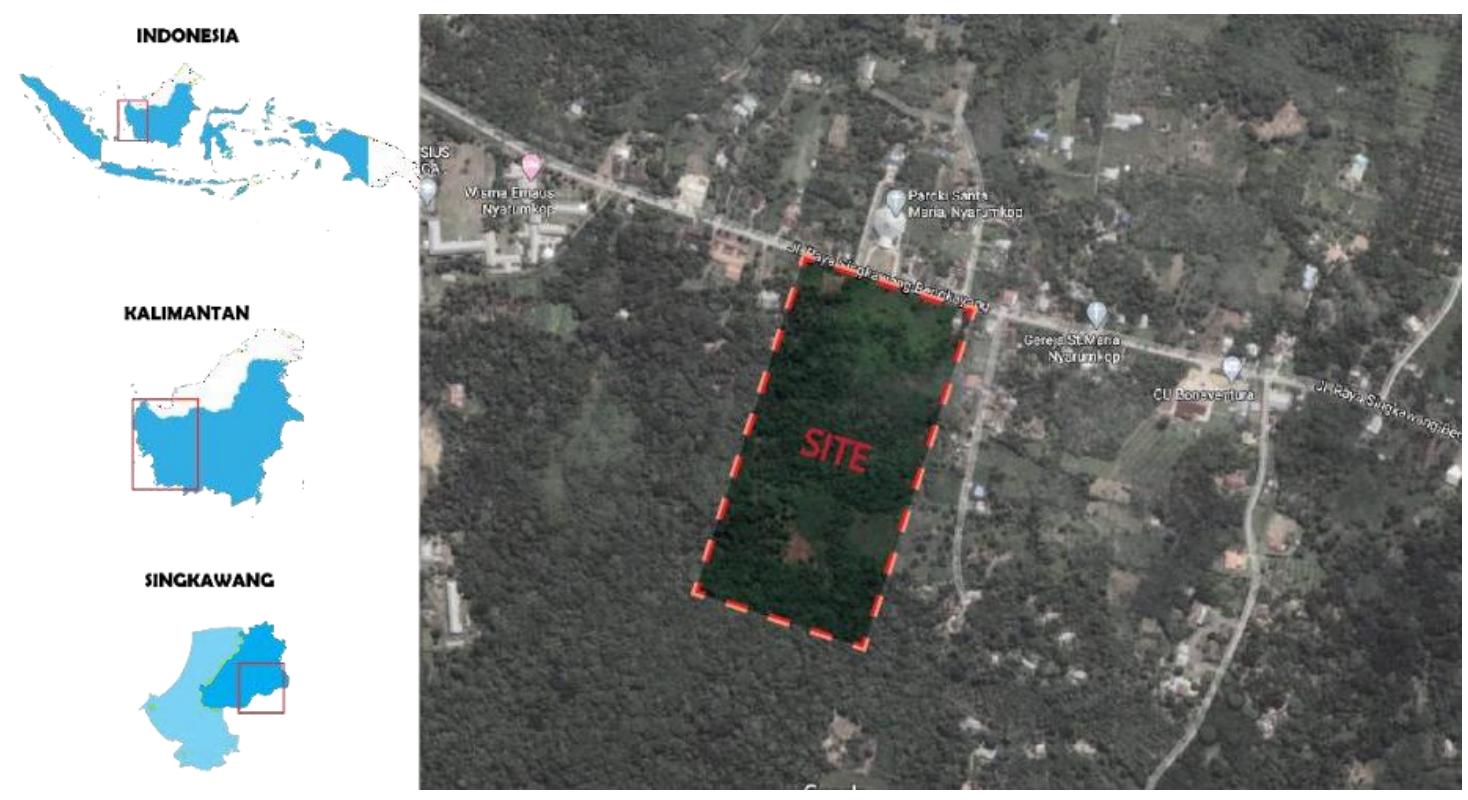

Gambar 3. Lokasi perancangan Wisata Outbound di Kota Singkawang Sumber: Penulis, 2020

Pada tapak perancangan kawasan dilakukan analisa terhadap tata guna lahan, sirkulasi, orientasi, informasi, dan bentuk bangunan. Sehingga menghasilkan konsep sebagai berikut:

1. Tata guna lahan, berdasarkan tingkat privasinya dibagi menjadi 4 zona, zona ublik, zona semi publik, zona privat, dan zona semi privat. Sedangkan berdasarkan kelompok penggunanya dibagi menjadi 5 zona, zona penerima, pengelola, outbound dewasa, outbound anak, dan zona perkemahan.

2. Sirkulasi pada Wisata Outbound di Kota Singkawang berdasarkan pelakunya, terdapat 2 sirkulasi yaitu sirkulasi pengunjung dan sirkulasi pengelola. Pada sirkulasi pengunjung terdapat 2 sirkulasi yaitu pedestrian dan sirkulasi kendaraan. Sirkulasi kendaraan berada di area penerima sedangkan pedestrian berada didalam kawasan yang menghubungkan area bermain. Area pedestrian diberikan vegetasi peneduh sedangkan sirkulasi kendaraan diberikan vegetasi pengarah. Sirkulasi pengelola terdiri dari sirkulasi kendaraan, dimana sirkulasi ini akan dilalui kendaraan untuk kebutuhan servis dan pengelolahan kawasan.

3. Informasi dan orientasi, orientasi utama kawasan mengarah ke Jl. Raya SingkawangBengkayang yang merupakan jalan utama. Orientasi di dalam kawasan mengarah ke sirkulasi di dalam kawasan. Informasi pada kawasan berupa penanda yang diletakkan pada masingmasing bangunan dan area bermain.

4. Bentuk dan tata massa bangunan, meletakkan bangunan menghadap sirkulasi di dalam kawasan sesuai zona serta meletakkan ruang terbuka pada area tertentu agar memperindah kawasan. 

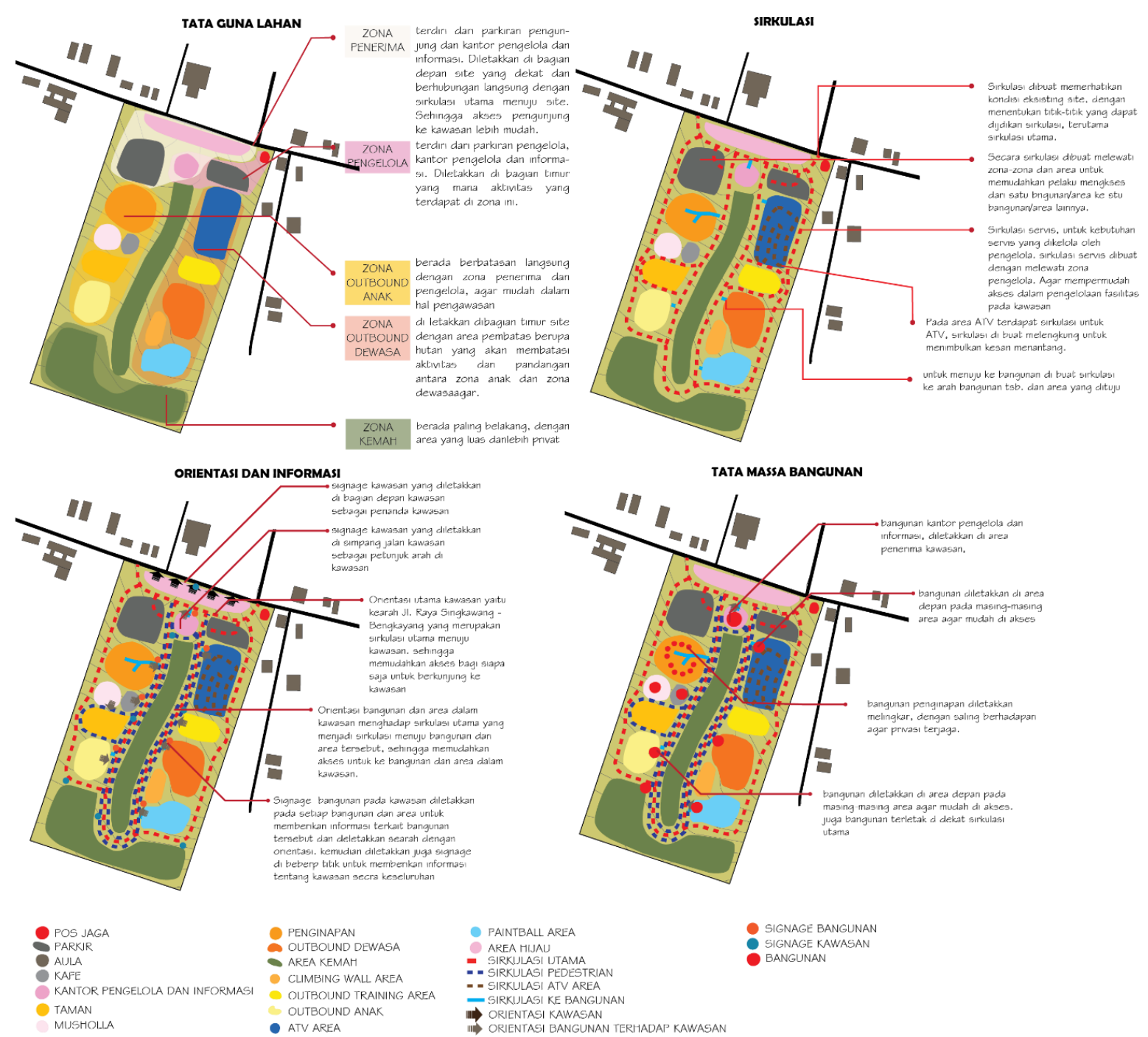

- signage bangunan SIGNAGE KAWASA
BANGUNAN

- STRLASI PEDESTRIa

ORIENTASI KAWASAN

Gambar 4. Konsep tapak kawasan Wisata Outbound di Kota Singkawang

Sumber: Penulis, 2020

\section{Konsep Bentuk}

Konsep bentuk pada kawasan Wisata Outbound di Kota Singkawang dianalisis secara makro. Bentuk bangunan secara garis besar merupakan massa solid persegi panjang sebagai bentuk dasar dengan penambahan dan pengurangan bentuk sebagai ide fasad. Kemudian memasukkan unsur fungsional dan kenyamanan sebagai pertimbangan bentuk. 
(1)

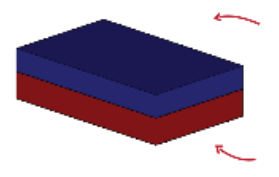

Bencuk awal banguanan berbentuk perseg parjang

terdapat 2 masa yang sama

2

Penambahan bentuk pada baglan depan dengan fungsi main entrance

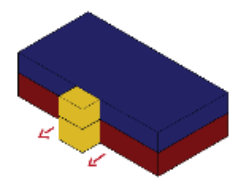

3

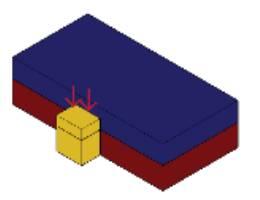

Pada bencukan untuk main entrance albuat berbeda dengan perbedaan ketingglar

(4)

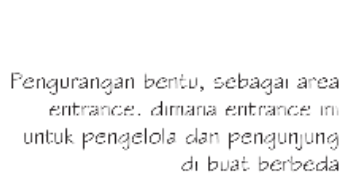

5

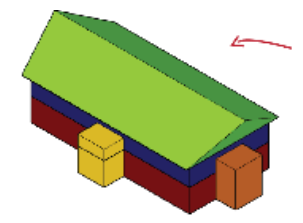

Perubshan bentuk, dar yang awal nya baglan atas berbentuk persegi payjang. meryad prisma segitiga, dengan fungs sebagai abap

\section{7}

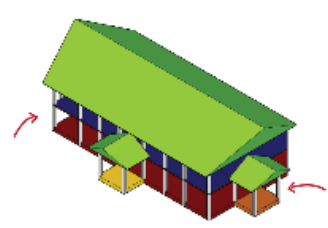

Kemodian, dengan konisep kawasarl yang alam joa d terapkan pada bangunan. yang mana pada barigunan dı buat semı indoor

yaltu di beberapa bagan, dibuat terbuka sehrigga terbentuk tlang tiang
8

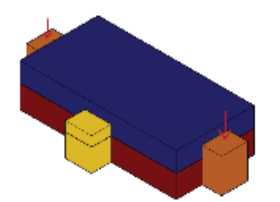

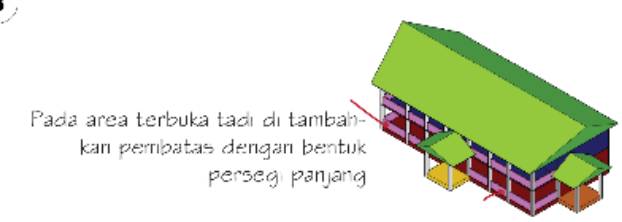

Gambar 5. Analisis bentuk bangunan

Sumber: Penulis, 2020

\section{Konsep Struktur}

Struktur pada kawasan ini terbagi menjadi 2 yaitu struktur kawasan dan strtuktur bangunan. Struktur kawasan yaitu Perkerasan area parkir akan menggunakan paving block hal ini dikarenakan paving block dapat menyerap air dan tidak membuat genangan selain itu paving block dapat dibentuk membentuk pola tulang ikan untuk mendapatkan daya tahan terhadap tekanan beban diatasnya. Kemudian untuk pedestrian menggunakan paving block yang dipasang membentuk pola anyaman tikar yang memiliki daya ikat sedang. Struktur bangunan dibagi menjadi 3 macam yaitu struktur atas, tengah dan bawah. Untuk struktur bawah pada bangunan didalam kawasan Wisata Outbound menggunakan pondasi batu kali dikarenakan kondisi eksisting site yang memiliki tanah keras sehingga lebih memerlukan pondasi batu kali, selain itu bangunan yang ada didalam kawasan direncanakan bangunan sederhana. Struktur tengah yaitu dinding akan menggunakan batako yang diplester dan dicat dengan menggunakan warna-warna yang memberikan kesan menyenangkan dan beberapa bangunan juga menggunakan dinding kayu. Untuk struktur atas menggunakan atap metal yang ringan dan awet serta struktur kayu yang mudah dalam hal pemasangan.

\section{Konsep Utilitas}

Sistem jaringan listrik pada kawasan ini berasal dari PLN yang menjadi sumber listrik utama kawasan. Kemudian untuk sumber listrik cadangan diperoleh dari genset. 


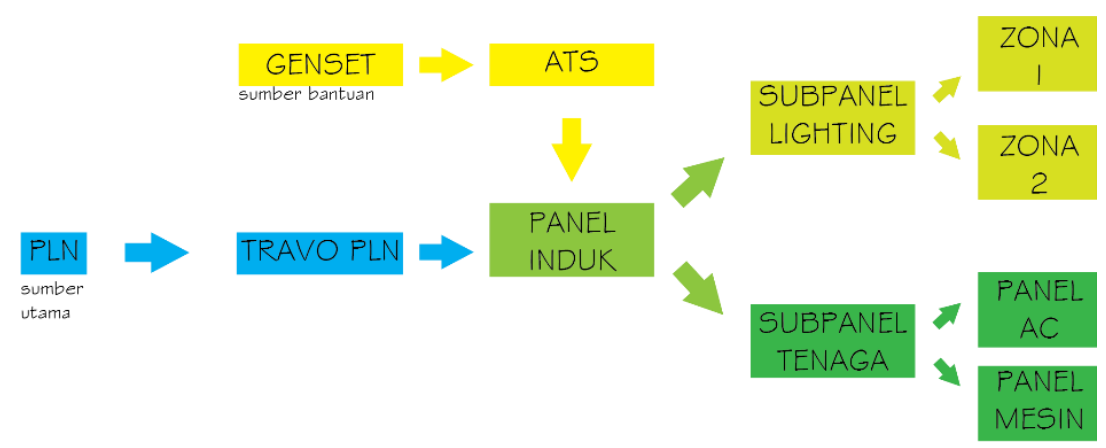

Gambar 6. Skema distribusi listrik pada kawasan Wisata Outbound di Kota Singkawang Sumber: Penulis, 2020

Air bersih pada kawasan ini bersumber dari PDAM , selain bersumber pada PDAM kawasan juga menampung air hujan sebagai cadangan. Sistem distribusi yang digunakan yaitu down feed yang disalurkan dari water tank.

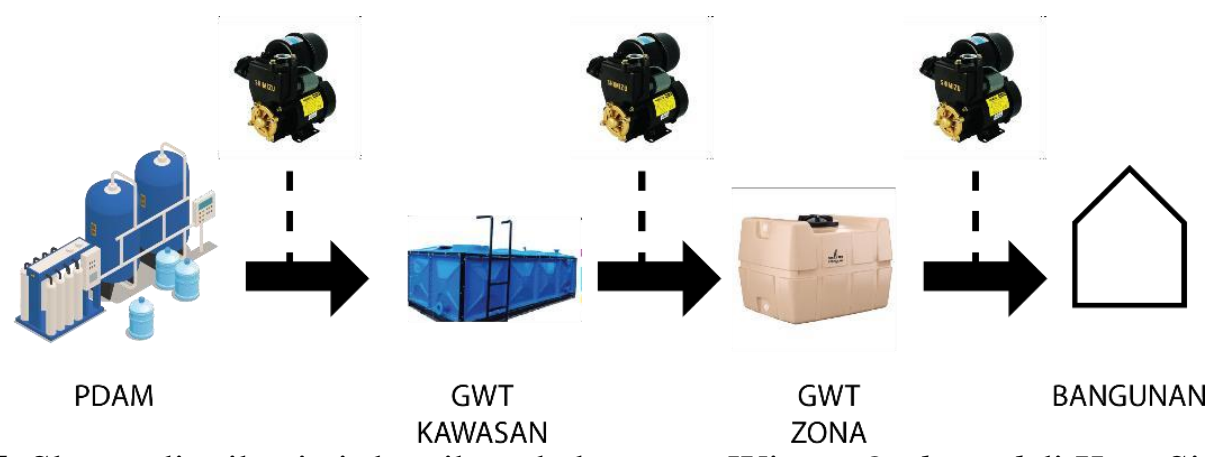

Gambar 7. Skema distribusi air bersih pada kawasan Wisata Outbound di Kota Singkawang Sumber: Penulis, 2020

Sistem distribusi yang digunakan untuk air kotor bada bangunan di kawasan ini yaitu seperti pada gambar berikut.

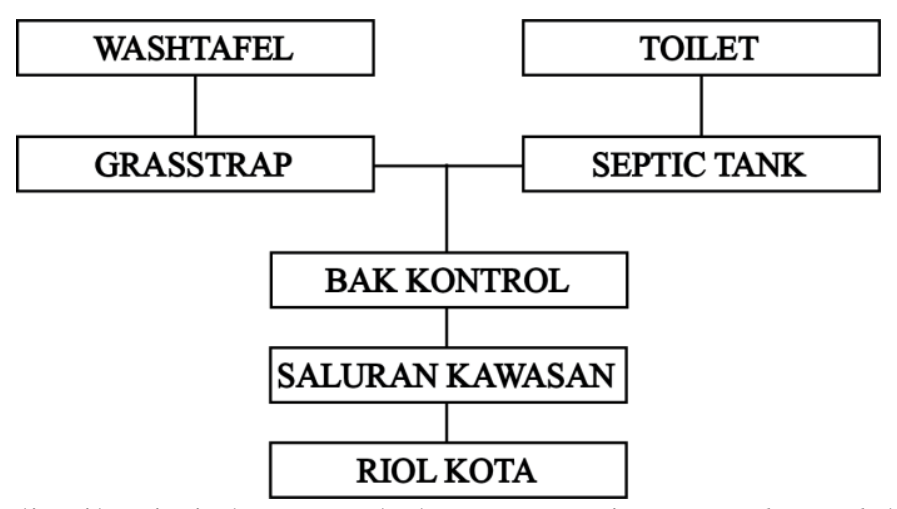

Gambar 8. Skema distribusi air kotor pada kawasan Wisata Outbound di Kota Singkawang

Sumber: Penulis, 2020

Wisata Outbound merupakan sebuah kawasan terbuka, jadi untuk sistem penanggulangan kebakaran pada kawasan akan disediakan hydrant halaman, perletakan hydrant pillarnya dengan radius 40 meter. Kemudian untuk setiap bangunan menggunakan PAR (Pemadam Api Ringan).

Sistem pengolahan sampah pada kawasan, disediakan tong sampah yaang terdiri dari 2 jenis, tong sampah anorganik dan tong sampah organik dengan penempatan tong sampah berdekatan. Kemudian, 2 tempat sampah tadi diletakkan secara berkelompok dengan jarak 15 meter. 


\section{Konsep Fisika Bangunan}

Fisika bangunan pada kawasan Wisata Outbound di Kota Singkawang ini terdiri dari 3 yaitu pencahayaan, penghawaan, dan akustika. Dari ketiga aspek tersebut, terdiri dari alami dan buatan. Pada aspek alami memanfaatkan kondisi alam yang memberi keuntungan untuk kenyamanan bangunan.

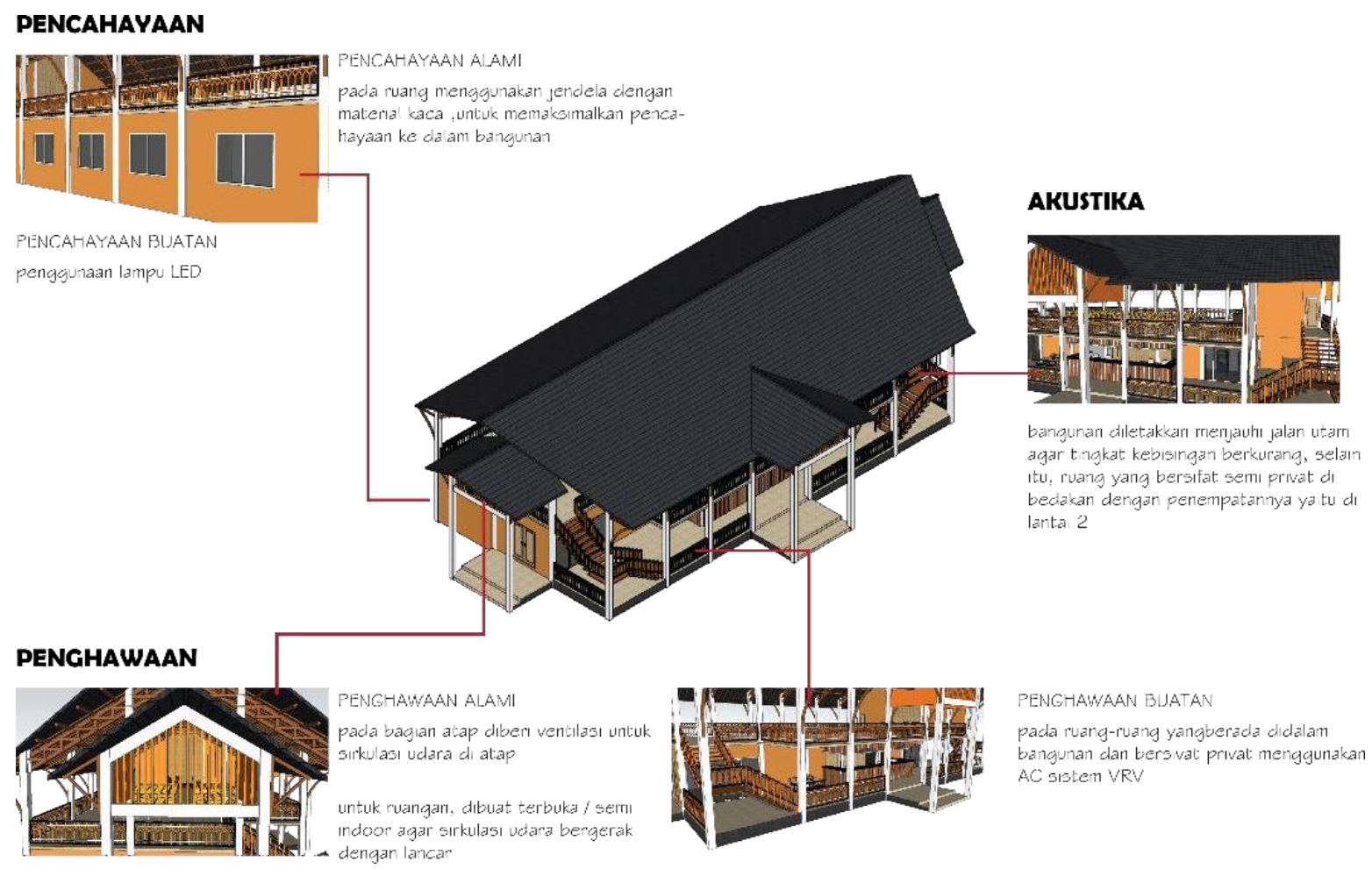

Gambar 9. Konsep fisika bangunan

Sumber: Penulis, 2020

\section{Hasil Perancangan}

Wisata Outbound di Kota Singkawang berdiri di atas lahan seluas 7,5 ha, yang memiliki fungsi utama rekreasi serta fungsi lainnya seperti komersil dan pengelola. Pada gambar dibawah ini, menunjukkan tataguna lahan, sirkulasi, orientasi, vegetasi, dan tata letak bangunan pada Wisata Outbound. 


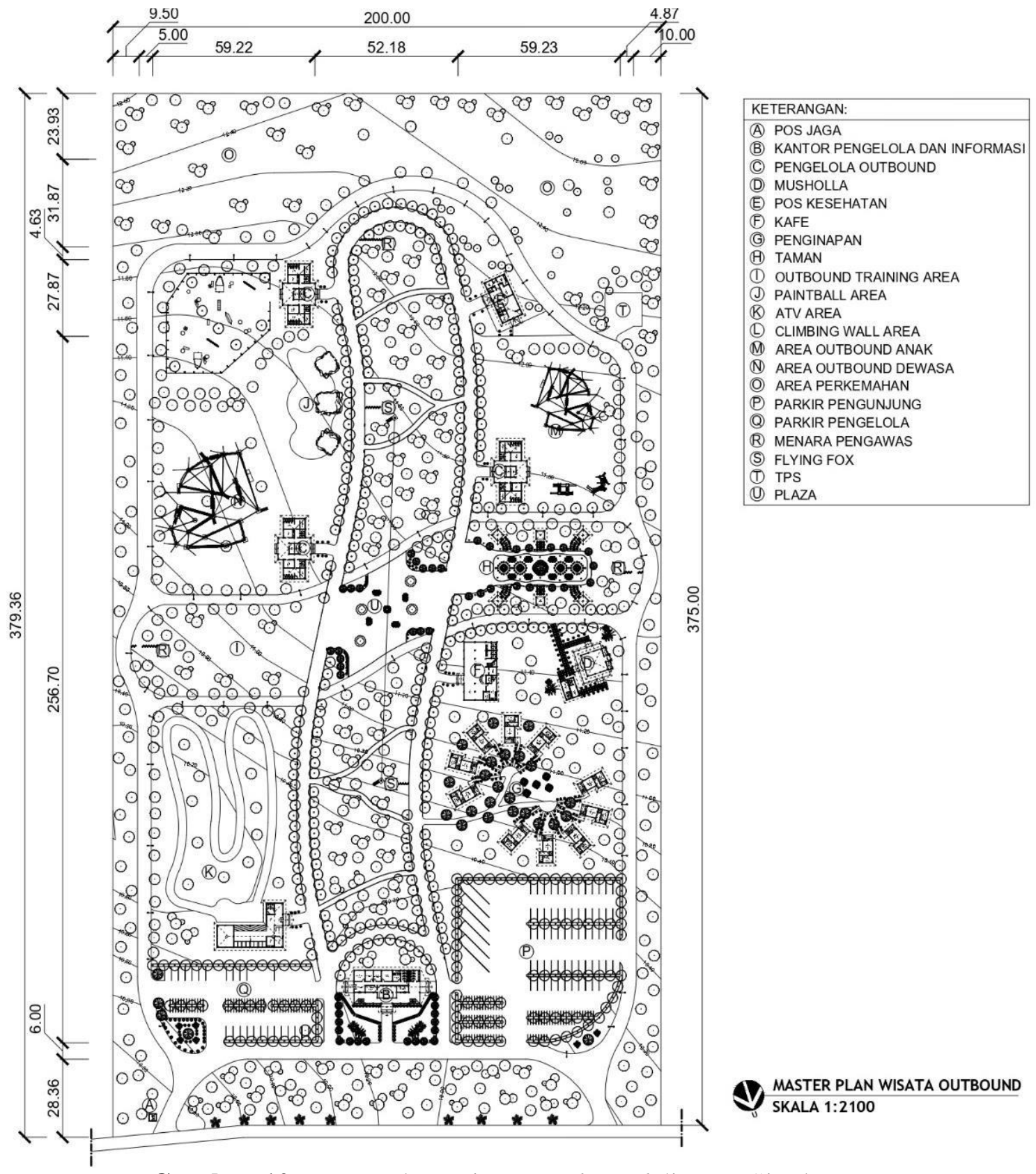

Gambar 10. Masterplan Wisata Outbound di Kota Singkawang Sumber: Penulis, 2020

Tampak kawasan merupakan gambaran kawasan dari empat sisi yaitu depan, belakang, kanan, dan kiri. Tampak juga menunjukkan skyline kawasan.

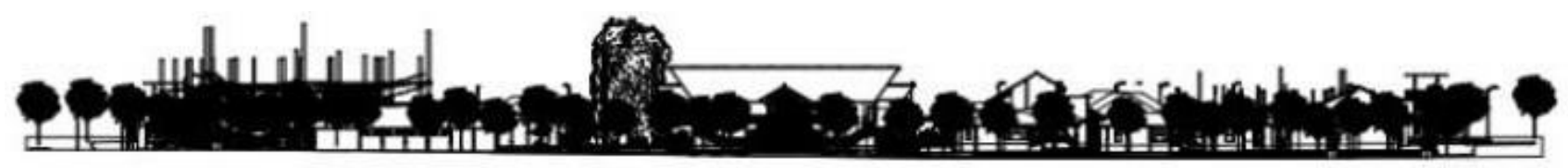

Gambar 11. Tampak depan Wisata Outbound di Kota Singkawang Sumber: Penulis, 2020

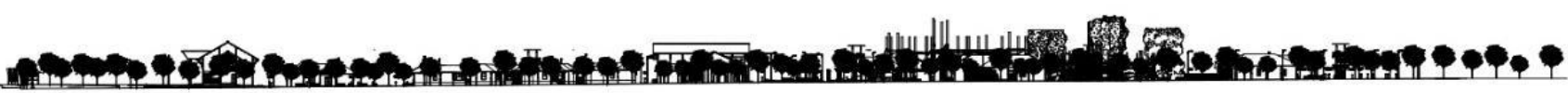

Gambar 12. Tampak kanan Wisata Outbound di Kota Singkawang

Sumber: Penulis, 2020 


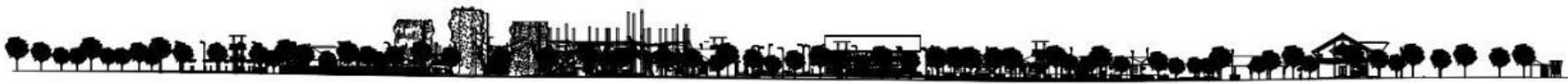

Gambar 13. Tampak kiri Wisata Outbound di Kota Singkawang

Sumber: Penulis, 2020

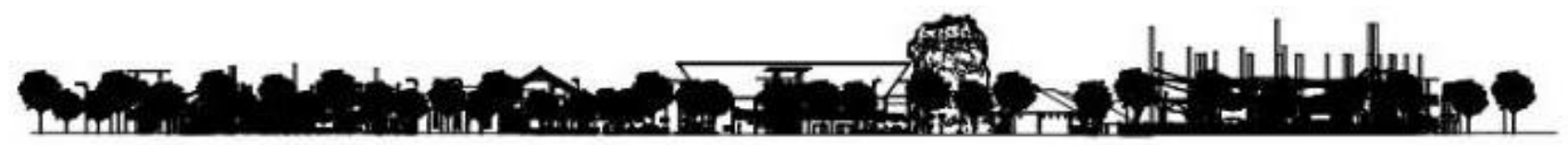

Gambar 14. Tampak belakang Wisata Outbound di Kota Singkawang

Sumber: Penulis, 2020

Potongan pada kawasan menunjukkan gambaran kawasan secara vertikal yang terpotong sesuai dengan garis potong pada mastesplan. Pada gambar potongan terlihat elevasi kawasan dan letak objek di kawasan.

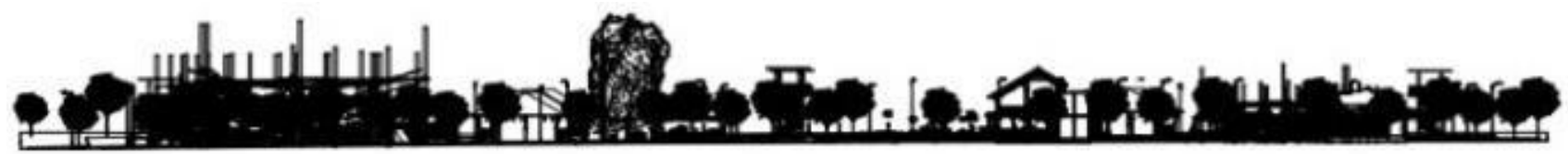

Gambar 15. Potongan A-A Wisata Outbound di Kota Singkawang

Sumber: Penulis, 2020

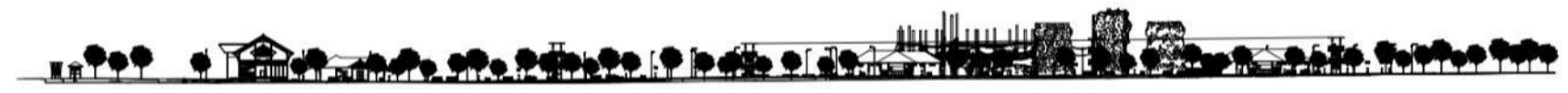

Gambar 16. Potongan B-B Wisata Outbound di Kota Singkawang

Sumber: Penulis, 2020

Eksterior kawasan Wisata Outbound di Kota Singkawang terdiri dari kawasan wisata yang terdapat area wisata dan fasilitas pendukung lainnya.

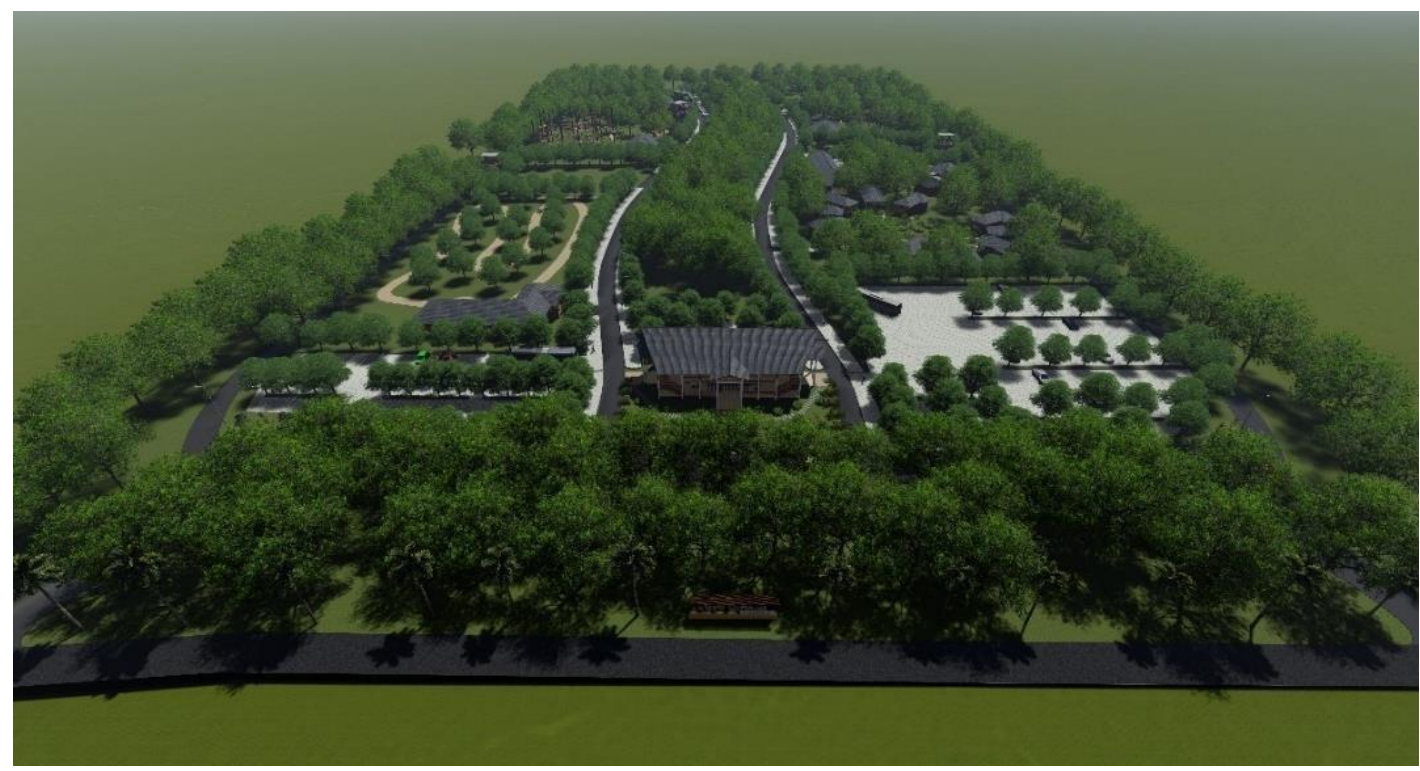

Gambar 17. Suasana eksterior kawasan 1

Sumber: Penulis, 2020 
Pada gambar 18 menunjukkan area entrance kawasan yang merupakan area masuk menunju kawasan yang berada di depan kawasan. Saat memasuki kawasan ini, pengunjung akan terlebih dahulu melewati area ini, dimana terdapat gapura dan pos jaga.

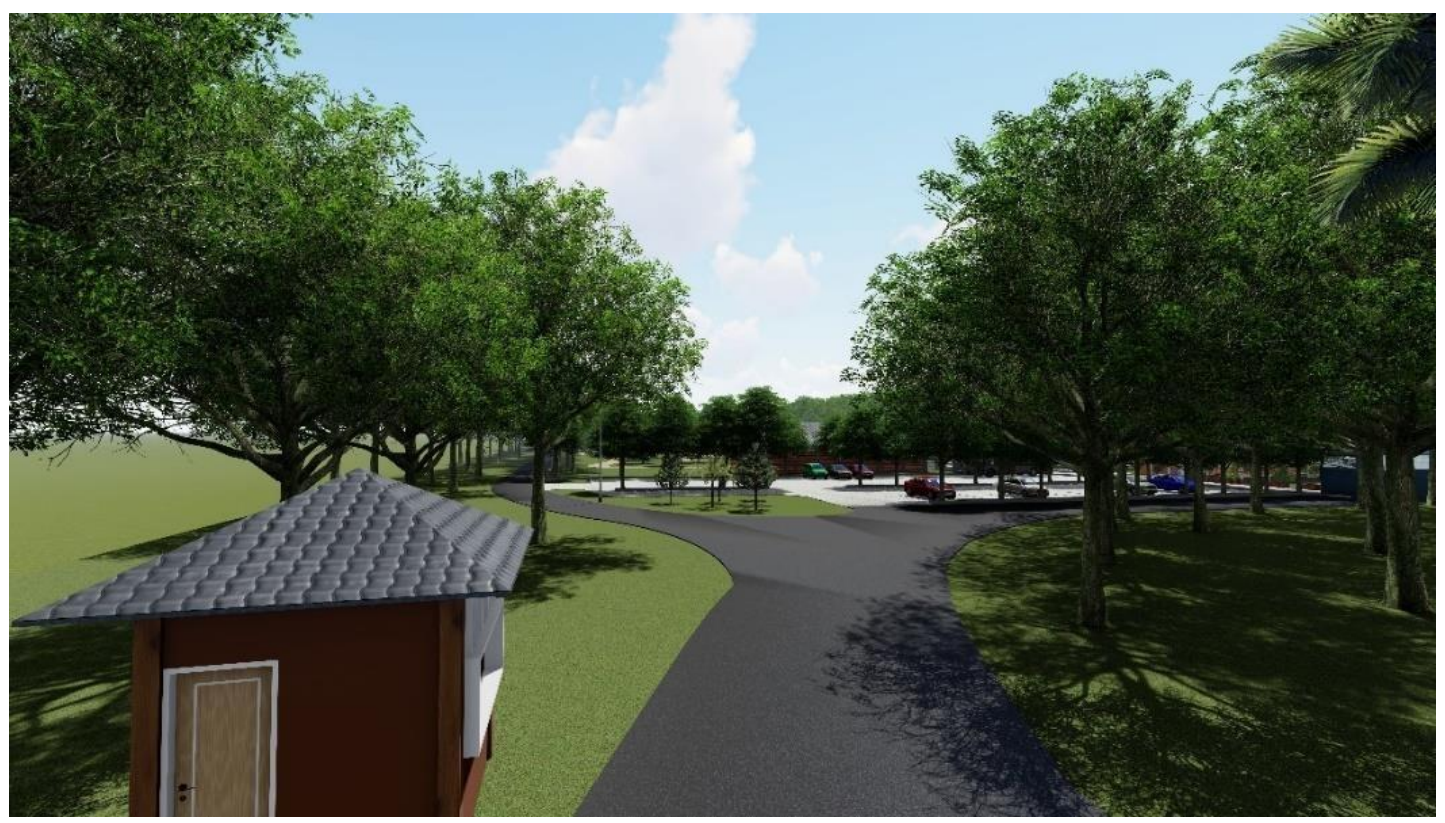

Gambar 18. Suasana eksterior kawasan 2

Sumber: Penulis, 2020

Pada gambar 19 menunjukan penanda utama kawasan yang terletak di area depan kawasan.

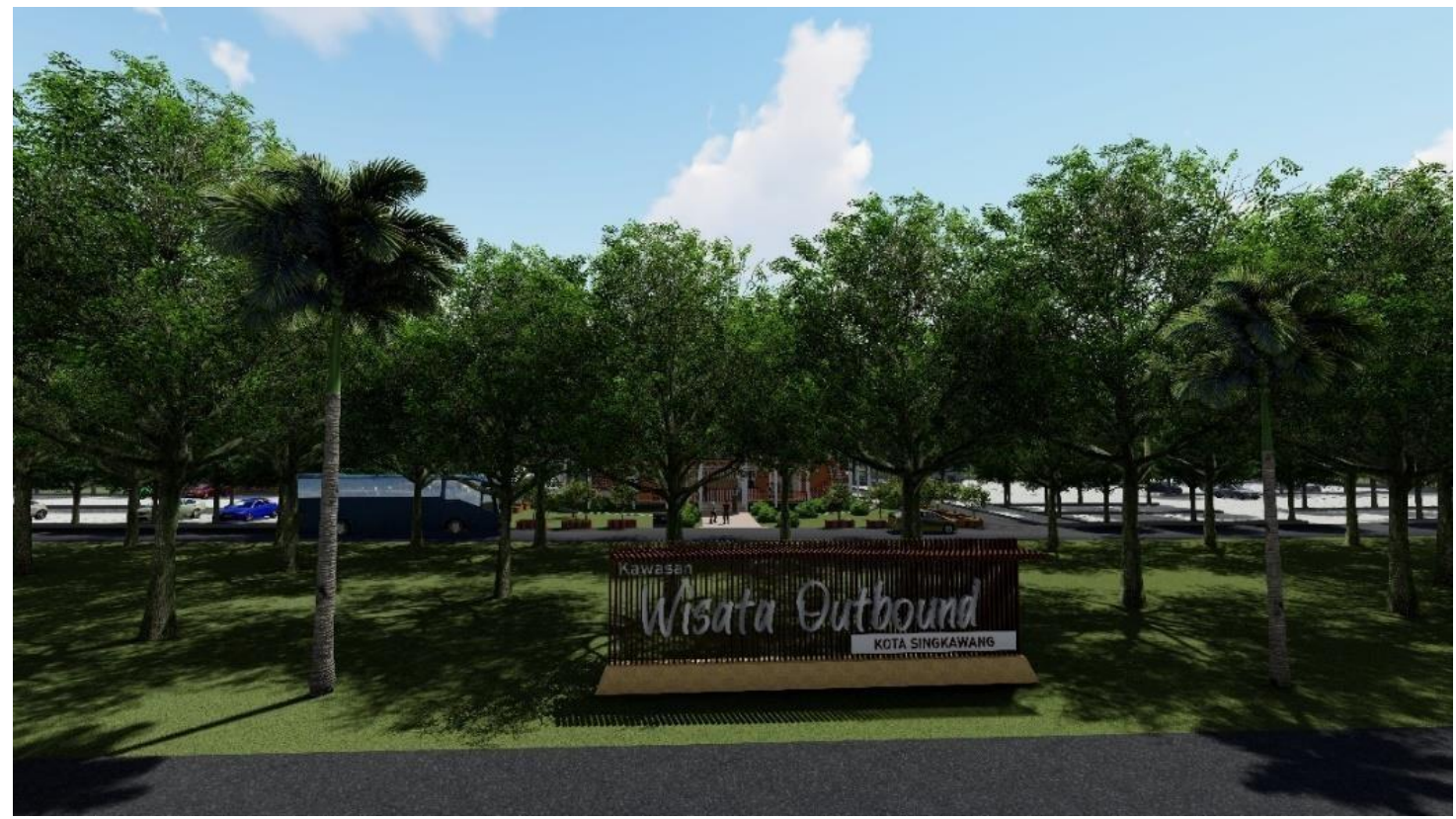

Gambar 19. Suasana eksterior kawasan 3

Sumber: Penulis, 2020

Pada gambar 20 merupakan bangunan kantor pengelola \& informasi, yang merupakan bangunan utama dari kawasan. Gambar 21 merukan bangunan kafe semi outdoor yang merupakan fasilitas pendukung di kawasan. 


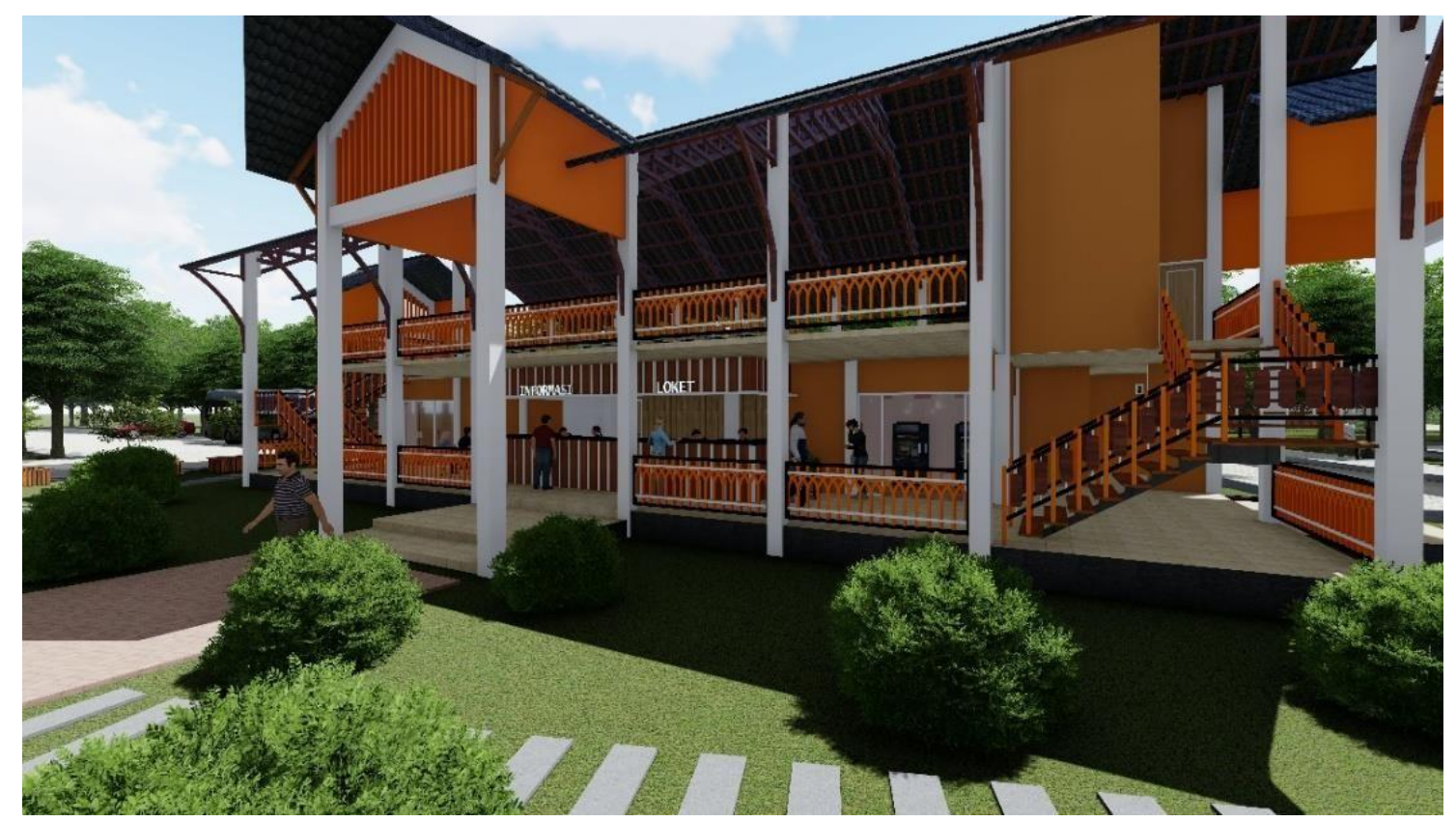

Gambar 20. Suasana interior kawasan 1

Sumber: Penulis, 2020

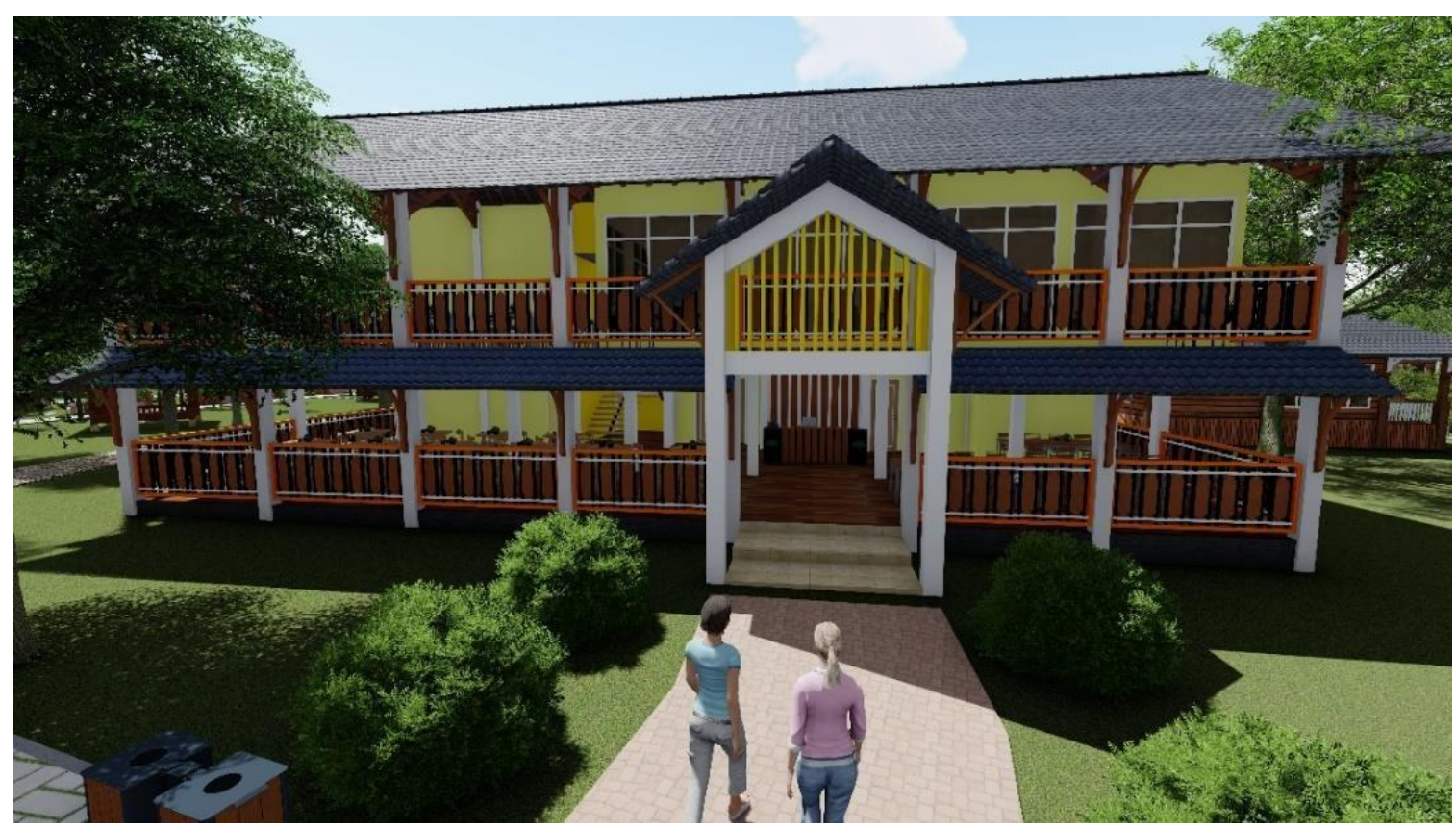

Gambar 21. Suasana interior kawasan 2

Sumber: Penulis, 2020

\section{Kesimpulan}

Berdasarkan hasil data yang telah dianalisis untuk mencapai tujuan dari perancangan kawasan Wisata Outbound di Kota Singkawang dengan konsep yang alami. Dengan memanfaatkan kondisi eksisting tapak perancangan. Perletakan zona dan tata guna lahan menjadi aspek penting yang perlu diperhatikan dalam perancangan wisata outbound ini sehingga memberikan kenyamanan akses terhadap kawasan. Selain itu, fasilitas-fasilitas yang terdapat pada kawasan wisata outbound dapat memberikan kesan yang nyaman dan alami. Wisata outbound sendiri memiliki fungsi utama sebagai area rekreasi (terutama outbound) dan fungsi-fungsi lain seperti komersil, pengelola, serta fasilitas umum. 


\section{Ucapan Terima Kasih}

Penulis mengucapkan syukur kepada Allah SWT dan terimakasih kepada keuarga dan saudara yang telah memberikan dukungan dalam bentuk moril maupun materil. Penulis juga mengucapkan terima kasih kepada dosen pembimbing yang telah banyak memberikan bimbingan, kritik, dan saran serta motivasi yang membangun terhadap penulis. Penulis juga mengucapkan terima kasih kepada rekan dan teman yang terlibat dalam proses penyelesaian tugas ini.

\section{Daftar Acuan}

Alikhshan, R. (2016, October 12). Sejarah dan Pengertian Outbound Secara Luas. Retrieved from http://skyadventure.com

Antoni, A., Angga, D., \& Akmal, M. (2018, November 15). Terkuak Fakta 1,35 Juta PNS Berkinerja Buruk. Retrieved from https://economy.okezone.com

Hartono, \& Dwi, B. (2019, August 19). SDM Aparatur Sipil Negaraa Juga Harus Unggul. Retrieved from http://antaranews.com

Kementerian Pariwisata Republik Indonesia. (2018). PERMENPAR RI Nomor 3 tahun 2018 tentang Kepariwisataan. Jakarta: Kementerian Pariwisata Republik Indonesia

Nanda, E. (2018, July 17). Sejarah dan Pengertian Umum Outbound. Retrieved from http:/maritimadventure.com

Nuraini, C. (2010). Metode Perancangan Arsitektur. Bandung: Karya Putra Darwati

Rendra. (2019, November 18). Pemkot Singkawang akan kembangkan objek wisata Batu Belimbing. Retrieved from https://kalbar.antaranews.com

Sekretariat Negara Republik Indonesia. (2009). Undang-Undang Nomor 10 tahun 2009 tentang Kepariwisataan. Jakarta: Sekretariat Negara Republik Indonesia

Yanuarius, V. (2018, January 5). PENGELOLAAN HUTAN : Kubu Raya Bikin Satu Data. Retrieved from http://papua.bisnis.com

Yoeti, O.A. 1996. Pengantar Ilmu Pariwisata. Bandung: Angkasa 